\title{
XRD-Thermal Combined Analyses: An Approach to Evaluate the Potential of Phytoremediation, Phytomining, and Biochar Production
}

\author{
Dario Fancello ${ }^{1}{ }^{\mathbb{D}}$, Jessica Scalco ${ }^{1}$, Daniela Medas ${ }^{1, *(\mathbb{D}}$, Elisa Rodeghero ${ }^{2}$, Annalisa Martucci ${ }^{2}$, \\ Carlo Meneghini ${ }^{3}$ and Giovanni De Giudici ${ }^{1}$ \\ 1 Department of Chemical and Geological Sciences, University of Cagliari, Cittadella Universitaria, \\ 09042 Monserrato, Italy; darfan@hotmail.it (D.F.); jescalco91@gmail.com (J.S.); gbgiudic@unica.it (G.D.G.) \\ 2 Department of Physics and Earth Sciences, University of Ferrara, I-44100 Ferrara, Italy; \\ elisa.rodeghero@unife.it (E.R.); annalisa.martucci@unife.it (A.M.) \\ 3 Department of Sciences, University Roma Tre, 00146 Rome, Italy; carlo.meneghini@uniroma3.it \\ * Correspondence: dmedas@unica.it
}

Received: 14 May 2019; Accepted: 1 June 2019; Published: 4 June 2019

check for updates

\begin{abstract}
A method for evaluating the potential of reuse of biomasses for economic purposes is here presented starting from a case study. Juncus acutus plants and rhizospheres were harvested from abandoned $\mathrm{Zn}-\mathrm{Pb}$ mine areas of southwest Sardinia (Italy). Thermogravimetry and Differential Thermal analyses were performed to evaluate the temperatures at which significant reactions occur. X-ray Diffraction (XRD) analysis was carried out on raw samples and on samples heated ex-situ (by a conventional diffractometer) or in-situ (by synchrotron-based diffraction). Raw samples mainly consist of quartz, phyllosilicates, and feldspars with minor amounts of sulfides, sulfates, and $\mathrm{Fe}, \mathrm{Pb}$, and $\mathrm{Zn}$ carbonates, concentrated in the rhizosphere. After heating, $\mathrm{Zn}$ and Fe oxides and willemite are observed in internal roots and stems, revealing the presence of these metals in the plant tissues. In-situ heating was less effective than ex-situ in revealing minor phases in organic samples, probably because the scarcity of oxygen within the sample holder did not allow the degradation of organic compounds and the oxidation of sulfides, resulting in a low quality XRD signal even if obtained with the high resolution ensured by a synchrotron light source. This method can be applied to plants from polluted sites for metal exploitation, and/or to biomasses from unpolluted sites for biochar production, since both applications take advantage of the knowledge of the minerals formed after heating.
\end{abstract}

Keywords: Juncus acutus; metal pollution; phytoremediation; conventional XRD; synchrotron-based XRD; thermal analyses

\section{Introduction}

The chemical and biological interaction between roots and soil in contaminated environments is a complex research field that involves biology, geology, chemistry, and environmental engineering. Its significance comes from the multiple potential applications, from the determination of toxicity threshold for plants [1], to the transfer of contaminants in the food chain [2], to the use of plants in phytoremediation. The latter field has acquired increasing interest during the last thirty years and it is widely recognized as one of the most promising techniques for limiting the diffusion of pollutants [3-7]. Plants can act as effective removers for both organic and inorganic compounds through different processes as rhizofiltration [8], phytostabilization [9], phytoextraction [10], phytovolatilization [11], and phytotransformation [12].

Phytoremediation is especially suitable for trace metals contamination because, unlike organic compounds, metals cannot be decomposed and thus they should be removed or at least immobilized. 
Metal removal and immobilization by plants depend on many factors as the species of plants, the type and the extent of contamination, the hydrological regime, the geochemical features of soil, and so on $[13,14]$. A wide variety of parameters strongly interacting with each other must be carefully examined prior to attempting a successful phytoremediation intervention. Several papers explore the different sides of this complex topic: from the choice of the better species to remove the metals of interest [15], to the adaptation of the species to the polluted environment [16]; from the role of root exudates in the chemical behavior of metals in the rhizosphere [17], to the symbiosis between roots and mycorrhizae [18] and/or bacteria [19]; from the migration of metals within the plant [20,21], to their physiological role/effect in the plant growth [22], to the possibility of recover these metals for commercial purposes [23].

Several species, named as hyperaccumulator, are able to concentrate metals in their organic tissues without suffering phytotoxic effects [24], and most of them are selective for one or more metals [5] (and references therein). Great interest is focused on such plants since they can make the phytoremediation intervention economically viable through the recovery of valuable elements. Other species cannot accumulate significant amounts of metals in the aerial parts but can stabilize them in the rhizosphere or on the root epidermis, as demonstrated by previous investigations for Vallisneria americana [25], Phragmites australis [26], Solanum lycopersicum [27], Lycopersicon esculentum [28], Euphorbia pithyusa L. [29], Pistacia lentiscus [30], and Juncus acutus [20,31]. These species cannot be harvested for metal recovery but could be reused for the biochar production that in turn can be employed in soil amendment/remediation [32,33]. This application has different ecological outcomes such as, stabilizing pollutants, making productive unused polluted lands, and solving the problem of biomass storage that, even if weakly contaminated, could produce metal leaching.

Despite the significant content of metals in both hyperaccumulator and "metal tolerant" plants, it is quite difficult to detect trace metal phases within their tissues by common X-ray Diffraction (XRD) at room temperature because metals are mainly bound to organic ligands as proteins, amino acids, and organic acids [34-36] resulting in low or absent signals in XRD patterns. For this reason, heating organic tissues up to their combustion or pyrolysis could help to reduce the background produced by organic compounds allowing for detection of possible trace metal-bearing mineral phases already present in the plants, or it could favor the formation of new minerals. Furthermore, the progressive heating of samples combined with thermogravimetry (TG) and Differential Thermal Analyses (DTA) could allow for recognition of the optimum temperature at which a given phase forms. Different applicative fields require this kind of information, for instance, phytomining $[37,38]$ in polluted environments and biochars production $[32,33,39]$ in unpolluted ones.

Juncus acutus is a halophyte plant and is considered a pioneer species as it can grow in extreme environments as salt marshes, dunes, and metal-polluted areas [20,26,31]. It is well known for its tolerance to high concentrations of metals [40] and for its capability to stabilize them in the rhizosphere or in the external roots. In addition, it has been successfully tested in hydroponic culture for the removal of $\mathrm{Zn}, \mathrm{Cd}, \mathrm{Ni}, \mathrm{Cr}$, and organic compounds as bisphenol A and antibiotics [41]. The importance of this species is not given just by its performance in phytoremediation but also by its widespread distribution throughout almost all of Europe, the Mediterranean Basin, northern Africa, Caucasus, western Asia, and also Baja California and Australia. Thus, its adaptability to different extreme environments and its worldwide diffusion, makes Juncus acutus a suitable candidate to perform local experiments whose results can be applied elsewhere.

In this paper, we present a study performed on samples of Juncus acutus harvested in an abandoned $\mathrm{Zn}-\mathrm{Pb}$ mine area from southwest Sardinia, (Italy). XRD analysis was performed on Juncus acutus samples at room temperature and after ex-situ and in-situ heating, combined with thermal analyses (TG and DTA). Four different aliquots were selected for each sample: rhizosphere, external root, inner root, and stem in order to investigate the mineralogy of the plant/soil system and how it is affected by heating processes. 


\section{Field Occurrence}

The Montevecchio-Ingurtosu mine district (southwestern Sardinia, Italy) is a complex of mining sites exploited since the first half of the 1800s to the end of the 1900s, mainly for $\mathrm{Pb}$ and $\mathrm{Zn}$ extraction. The cessation of mining activities left behind millions of $\mathrm{m}^{3}$ of dumps, open pits, and a strong widespread metal pollution [42]. The mineralizations are hosted within the Variscan metamorphic basement and close to a carboniferous batholith known as Arburese granite [43] (and references therein). The primary mineralization, linked to the hydrothermal activity subsequent to the granite emplacement at shallow crustal levels [44], mainly consists of galena (PbS) and sphalerite ( $\mathrm{ZnS})$, with minor amounts of pyrite $\left(\mathrm{FeS}_{2}\right)$ and chalcopyrite $\left(\mathrm{CuFeS}_{2}\right)$ and accessory sulfide phases as arsenopyrite (FeAsS), greenockite $(\mathrm{CdS})$, enargite $\left(\mathrm{Cu}_{3} \mathrm{AsS}_{4}\right)$, argentite $\left(\mathrm{Ag}_{2} \mathrm{~S}\right)$, etc. The oxidation of these minerals produced sulfates, carbonates, and hydroxides as smithsonite $\left(\mathrm{ZnCO}_{3}\right)$, cerussite $\left(\mathrm{PbCO}_{3}\right)$, malachite $\left(\mathrm{Cu}_{2}\left(\mathrm{CO}_{3}\right)(\mathrm{OH})_{2}\right)$, azurite $\left(\mathrm{Cu}_{3}\left(\mathrm{CO}_{3}\right)_{2}(\mathrm{OH})_{2}\right)$, anglesite $\left(\mathrm{PbSO}_{4}\right)$, hemimorphite $\left(\mathrm{Zn}_{4}\left(\mathrm{Si}_{2} \mathrm{O}_{7}\right)(\mathrm{OH})_{2} \cdot \mathrm{H}_{2} \mathrm{O}\right)$, goethite $(\mathrm{FeO}(\mathrm{OH}))$, etc. Lead mineralization is commonly associated with a quartz + barite gangue, whereas $\mathrm{Zn}$ mineralization is found within a carbonate gangue made up of calcite, dolomite, and ankerite.

The samples of Juncus acutus were harvested along the banks of two streams that flow within the above described mine district (Figure 1). The seasonal behavior of the two selected streams-Rio Irvi, Casargiu [45,46] and Rio Naracauli [47], Ingurtosu-is due to the climate of southern Sardinia, characterized by a long dry season starting in May and ending in September or October with minimum rainfalls in July and maximum in November [48]. Sampling was performed at the end of the dry period and thus with low levels in the streams.

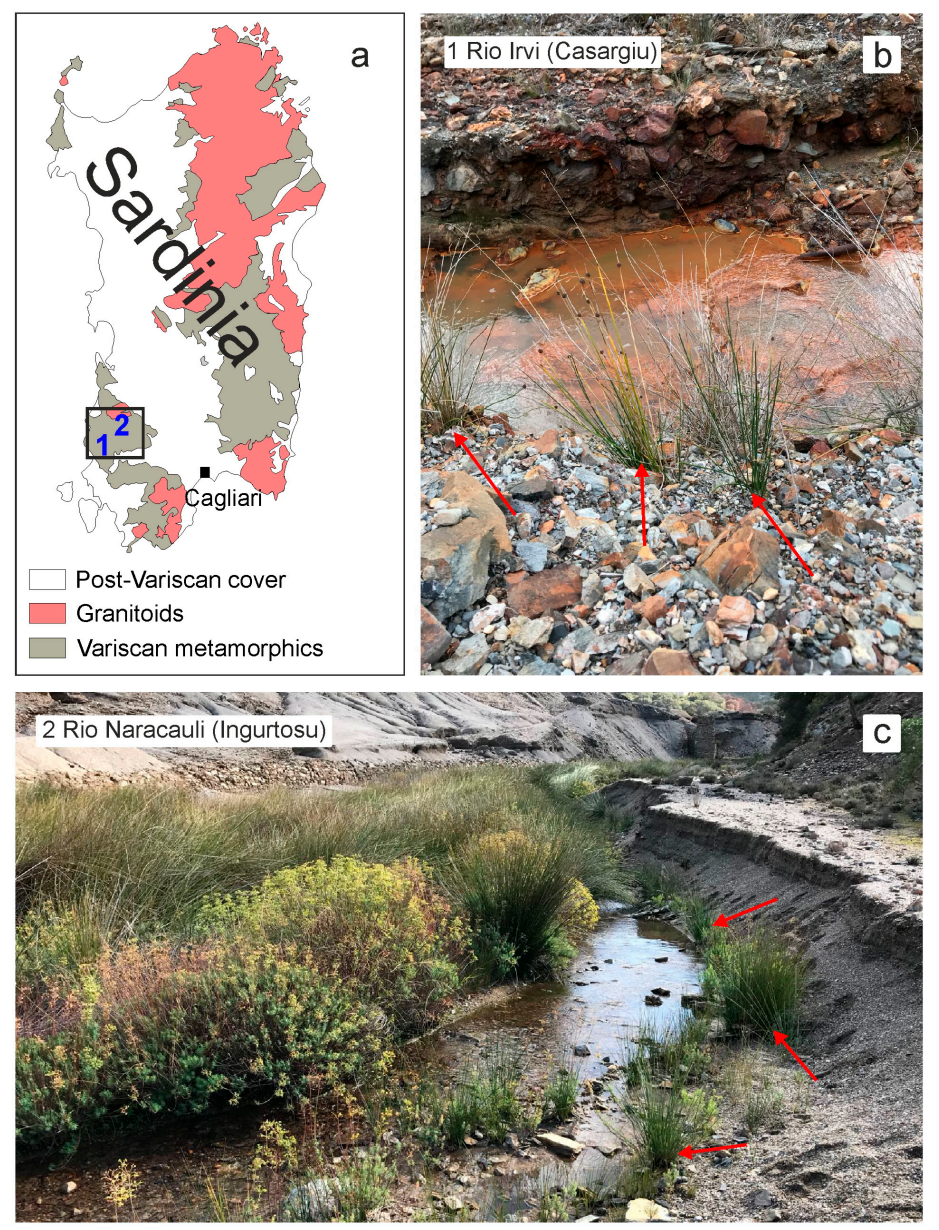

Figure 1. Schematic geological map of Sardinia (a). Sampling sites along Rio Irvi (b) and Rio Naracauli (c). Red arrows indicate the harvested plants. 


\section{Materials and Methods}

Three samples of Juncus acutus including the whole plant, its roots and rhizosphere were collected from each sampling site. From each sample rhizosphere, external surface of roots (epidermis), internal roots (defined in this study as the roots without the epidermis) and stems (Figure 2) were manually separated with a scalpel under a reflected light microscope. Rhizosphere samples (here considered as the $2 \mathrm{~mm}$ of soil surrounding the roots) were dried at room temperature and grinded in an agate mortar whereas organic samples were washed with de-ionized water, dried at $40{ }^{\circ} \mathrm{C}$ and grinded in a mill (Retsch ZM200).

Clayey and silty fractions of rhizosphere samples were sequentially separated by the wet gravity separation method according to the "Stokes law". De-ionized water was used as dispersive phase and sodium hexametaphosphate and sodium carbonate as deflocculant. This treatment was required to better characterize clayey minerals during XRD analyses.

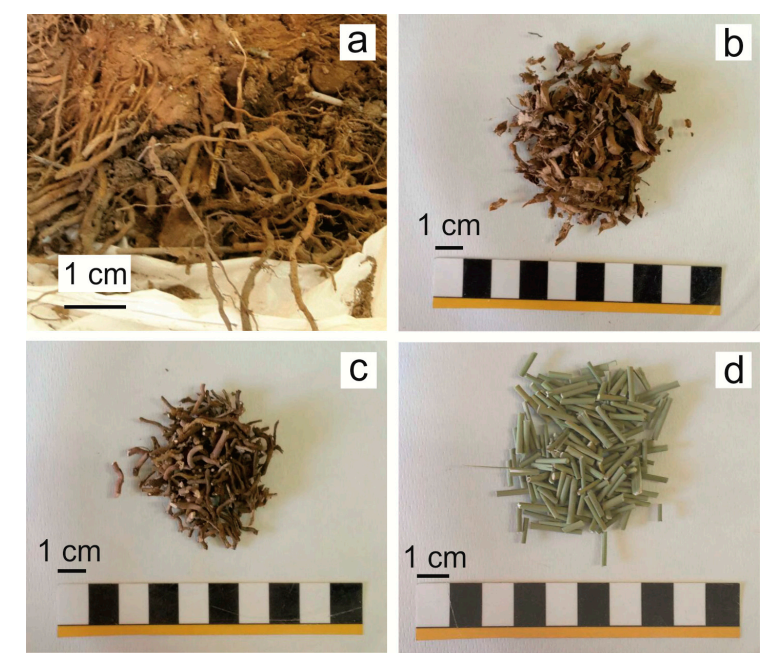

Figure 2. Images of rhizosphere (a), external surface of roots (epidermis) (b), internal roots (c), and stems (d) of Juncus acutus collected along the Rio Irvi (SW Sardinia).

The concentrations of $\mathrm{Ca}, \mathrm{Mg}, \mathrm{Na}$, and $\mathrm{K}$ for all samples were determined through Inductively Coupled Plasma-Optical Emission Spectrometry (ICP-OES) analysis after acid digestion at the Department of Chemical and Geological Sciences of Cagliari University (Italy), according to the procedure reported by Medas et al. [20]. To evaluate the analytical precision of the acid digestion procedure, samples were digested and analyzed in duplicate. The accuracy was evaluated processing samples together with blanks and a reference material (polish Virginia Tobacco leaves-INCT-PVTL-6), prepared with the same mixture. For ICP-OES analysis, procedural blanks, standard solutions, and reference solutions (SRM 1643e and EnviroMAT Drinking Water, High EP-H-3 and Low EP-L-3) were analyzed after every five samples to estimate potential contaminations, accuracy, and precision. Also, minor elements' data reported by Medas et al. [20] are considered.

Thermogravimetric and Differential Thermal Analyses were performed, at the Department of Physical and Earth Sciences of Ferrara University (Italy), on stem and rhizosphere samples from the Rio Irvi site in order to identify the main physical/mineralogical reactions occurring during the progressive heating as well as to understand their thermodynamic. Thermogravimetric (TG/DTG) and Differential Thermal Analysis (DTA) were simultaneously performed by Netzsch STA 409 instrument, with a constant $10{ }^{\circ} \mathrm{C} \mathrm{min}-1$ heating rate from 30 to $900^{\circ} \mathrm{C}$ in streaming dry air.

Three kind of data were obtained: (i) TG gives quantitative information on the change in sample mass as a function of the temperature; (ii) DTA gives qualitative information on the endo- or exothermicity of transformations occurring during the thermal treatment; and (iii) the derivative of the 
TG curve (DTG) allows us to detect changes in the slope of the TG curve, occurring, for example when thermal events overlap, which might otherwise not be detected.

X-ray diffraction (XRD) analyses on both raw and heated samples harvested from Rio Irvi and Rio Naracauli, were performed following two different procedures. Samples from Rio Irvi were analyzed, at the Department of Physical and Earth Sciences of Ferrara University (Italy), before and after ex-situ heating at $120^{\circ}, 300^{\circ}$, and $600^{\circ} \mathrm{C}$ in a muffle under atmospheric air flux. Heating rate was about $10^{\circ} \mathrm{C} / \mathrm{min}$ and the step temperature was kept for 30 minutes. XRD patterns were collected by a Bruker-AXS D8 diffractometer with Cu K $\alpha$ radiation $(\lambda=1.54056 \AA)$, equipped with the Soil-X detector; operating conditions were $40 \mathrm{kV}$ and $40 \mathrm{~mA}, 2 \theta$ range $5-80^{\circ}$ and $0.02^{\circ}$ of step size.

Samples from Rio Naracauli were analyzed before and during in-situ heating at the MCX (Materials Characterisation by X-ray diffraction) beamline (experiment number 20140061) of Elettra Synchrotron (Trieste, Italy) [49] using the translating imaging plate detector (TIP) available at the beamline, the TIP set-up provides a furnace operating under vacuum conditions suitable for in-situ XRD in the RT- $1000^{\circ} \mathrm{C}$ temperature range [50]. The samples were placed in a borosilicate capillary, the XRD patterns were firstly measured at room temperature (static), then during heating at different temperatures: $200{ }^{\circ} \mathrm{C}$, $400^{\circ} \mathrm{C}$, and $600^{\circ} \mathrm{C}$ for root samples and $400^{\circ}, 800^{\circ}$, and $1000^{\circ} \mathrm{C}$ for stem ones. During the measurement the capillary rotates to ensure a randomized orientation of the crystallites in the sample. X-ray beam wavelength was $\lambda=0.82594 \AA$, XRD patterns were collected in the $2-120^{\circ} 2 \theta$ range. The XRD data were integrated by the Fit2D software [51] and converted to the .xrdml format using the PowDLL software [52]. All XRD patterns were analyzed by the X'Pert HighScore Plus software in order to identify the crystallographic phase composition.

\section{Results}

\subsection{Chemical Characterization}

Selected major and minor element concentrations are reported in Table 1. Rhizosphere samples from Rio Irvi and Rio Naracauli show similar concentrations of Mg (3360 and 2680 ppm, respectively), $\mathrm{Na}$ (2510 and 2390 ppm, respectively), and K (12,600 and 16,500 ppm, respectively) while they significantly differ in metals linked to the ore mineralization. Rio Irvi rhizosphere shows a higher concentration of Fe (71000 ppm) Mn (5900), and Zn (26,000 ppm) than Rio Naracauli ones (Fe = 53,800 ppm, $\mathrm{Mn}=1800 \mathrm{ppm}$, and $\mathrm{Zn}=18,300 \mathrm{ppm})$. Conversely, the $\mathrm{Pb}$ concentration is extremely higher in Rio Naracauli (53,600 ppm) than in Rio Irvi (1900 ppm). In the plant tissues, the higher concentrations of Fe, $\mathrm{Mn}, \mathrm{Zn}$, and $\mathrm{Pb}$ are found in the external root and tend to decrease moving to the internal root and to the stem. An exception is represented by Fe and Mn whose concentrations increase from internal root to stem in Juncus acutus from the Rio Irvi. The relative concentration of metals in the different tissues of the Juncus acutus indicates that the translocation of metals within the plant is not very efficient (see Medas et al. [20] for more details).

Table 1. Chemical analysis of selected major and minor elements of collected samples. * indicates data reported from Medas et al. [20].

\begin{tabular}{|c|c|c|c|c|c|c|c|c|c|}
\hline Sample & $\begin{array}{c}\mathrm{Al} * \\
\mathrm{mg} / \mathrm{kg}\end{array}$ & $\begin{array}{c}\mathrm{Fe}^{*} \\
\mathrm{mg} / \mathrm{kg}\end{array}$ & $\begin{array}{c}\mathrm{Mg} \\
\mathrm{mg} / \mathrm{kg}\end{array}$ & $\begin{array}{c}\mathrm{Mn} * \\
\mathrm{mg} / \mathrm{kg}\end{array}$ & $\begin{array}{c}\mathrm{Ca} \\
\mathrm{mg} / \mathrm{kg}\end{array}$ & $\begin{array}{c}\mathrm{Na} \\
\mathrm{mg} / \mathrm{kg}\end{array}$ & $\begin{array}{c}\mathrm{K} \\
\mathrm{mg} / \mathrm{kg}\end{array}$ & $\begin{array}{c}\mathrm{Zn} * \\
\mathrm{mg} / \mathrm{kg}\end{array}$ & $\begin{array}{c}\mathrm{Pb} * \\
\mathrm{mg} / \mathrm{kg}\end{array}$ \\
\hline \multicolumn{10}{|l|}{ Rio Irvi } \\
\hline Rhizo & 34,200 & 71,000 & 3360 & 5900 & 5270 & 2510 & 12,600 & 26,000 & 1900 \\
\hline Ext. root & 4200 & 9100 & 3480 & 640 & 6490 & 3320 & 2520 & 14,900 & 1400 \\
\hline Int. root & 450 & 740 & 1850 & 60 & 3890 & 1950 & 970 & 9700 & 850 \\
\hline Stem & 600 & 1400 & 1790 & 90 & 2250 & 4470 & 6080 & 1800 & 90 \\
\hline \multicolumn{10}{|c|}{ Rio Naracauli } \\
\hline Rhizo & 40,200 & 53,800 & 2680 & 1800 & 2290 & 2390 & 16,500 & 18,300 & 53,600 \\
\hline Ext. root & 22,200 & 30,900 & 1770 & 1100 & 1640 & 1890 & 12,100 & 11,700 & 24,300 \\
\hline Int. root & 2000 & 2800 & 220 & 80 & 430 & 510 & 2560 & 1600 & 2100 \\
\hline Stem & 120 & 112 & 980 & 14 & 2020 & 2170 & 11,400 & 290 & 9.1 \\
\hline
\end{tabular}




\subsection{Thermal Analysis}

The diagrams reporting TG, DTG, and DTA for rhizosphere and stem samples are shown in Figure 3a,b. Samples highlight a different behavior between themselves: the rhizosphere undergoes a total weight loss lower than $10 \%$ at the end of the experiment whereas the stem is completely burned showing a total weight loss of $\approx 96 \mathrm{wt}$. \%. The thermal-analysis curves show a small weight loss (about 1 and $3 \mathrm{wt}$. \% for the rhizosphere and the stem, respectively) at low temperatures in association with an endothermic reaction (see DTA curve in Figure 3a,b), which may be attributed to surface-water effects. Therefore, except for this occurrence, two significant events take place in both the rhizosphere and stem samples, as highlighted by the DTG curves. At about $120^{\circ} \mathrm{C}$, a decrease of weight loss rate occurs and remains quite constant up to $220^{\circ} \mathrm{C}$. Then, a new increase of weight loss rate, having its maximum velocity around $300{ }^{\circ} \mathrm{C}$, can be observed. This increase is associated with an exothermic reaction as shown by DTA curves. The last significant variation in weight loss was achieved between 400 and $500{ }^{\circ} \mathrm{C}$ (stem and rhizosphere, respectively) until the end of the measurement. In this temperature range, the DTG peaks have indicated that the main weight loss, was reached more slowly in the stem sample. The last significant variation of the weight loss rate is observed at about $500{ }^{\circ} \mathrm{C}$ in the rhizosphere samples and at $680{ }^{\circ} \mathrm{C}$ in the stems. These significant events accompanied by the occurrence of large and asymmetric peaks, highlighted by the DTG curves, are interpreted as a result of phyllosilicate dehydroxylation. Higher temperatures do not produce significant effects in the stems because the combustion of the stem samples is completed (weight loss $\approx 95 \mathrm{wt}$. $\%$ of the initial weight). Rhizosphere samples undergo a quite constant weight loss up to $720^{\circ} \mathrm{C}$, and then this process becomes slower at even higher temperatures. The weight loss steps, and the related endothermic and exothermic reactions as shown by DTA curves. Exothermic reactions occurring in both stem and rhizosphere samples above $220^{\circ}$ can be associated to the combustion for the former and to a mineralogical reaction for the latter.
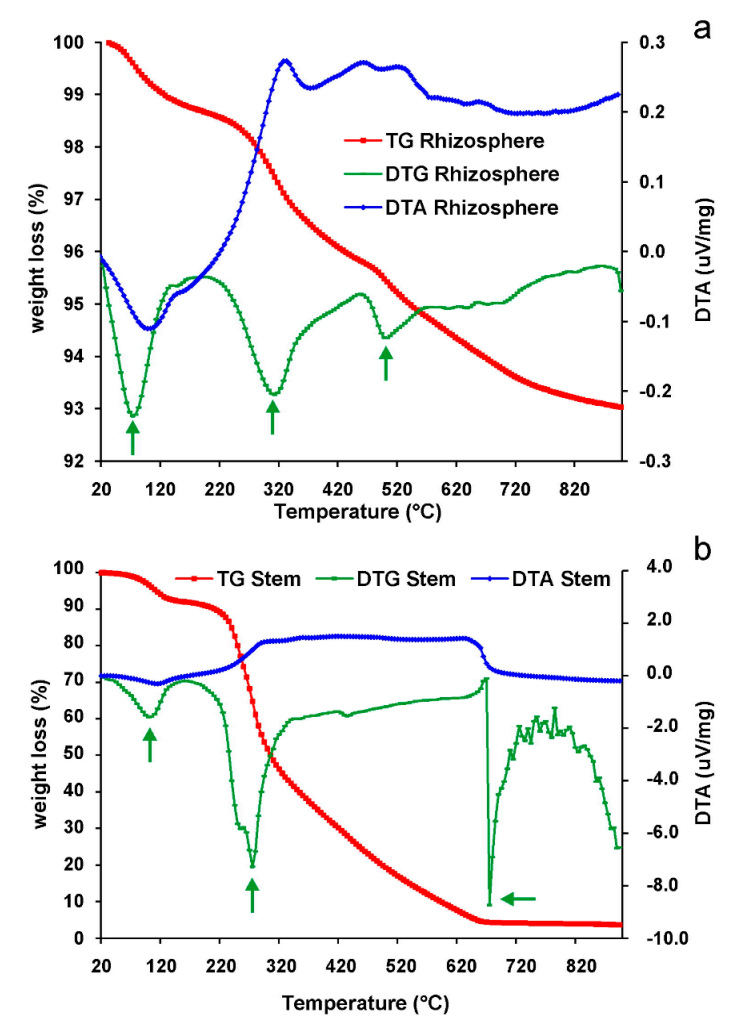

Figure 3. Results of thermal analyses on the rhizosphere (a) and the stem (b) from Rio Irvi samples. Green arrows indicate the main negative peaks in the derivative of the thermogravimetry (DTG) curves. 
Following the results of thermal analysis, three different temperatures of $120^{\circ}, 300^{\circ}$, and $600{ }^{\circ} \mathrm{C}$, approximately corresponding to the changes in weight loss rate, were chosen for the ex-situ and in-situ heating of samples to analyze by XRD.

\subsection{XRD Characterization of the Rio Irvi Samples}

Samples of rhizosphere, external surface of roots (epidermis), internal roots, and stems were analyzed by XRD before and after ex-situ thermal treatment. Detected inorganic and organic phases are summarized in Table 2.

Table 2. Mineral assemblages of samples from Rio Irvi at the different temperatures of the heating ramp. Abbreviation are: Qtz, quartz; Mus, muscovite; Feld, feldspars; Clay, clayey minerals; Sid, siderite; $\mathrm{H}-\mathrm{Zn}$, hydrozincite; $\mathrm{Zn}$-ox, zinc oxides; Fe-ox, iron oxides; Wil, willemite; $\mathrm{CaO}$ and $\mathrm{MgO}$, calcium and magnesium oxides; Gph, graphite; Anhy, anhydrite; Arc, arcanite; Syl, sylvite; Cell, cellulose; L-cys, L-cysteine.

\begin{tabular}{|c|c|c|c|c|c|c|c|c|c|c|c|c|c|c|c|c|c|}
\hline Rio Irvi & Qtz & Mus & Feld & Clay & Sid & H-Zn & Zn-ox & Fe-ox & Wil & $\mathrm{CaO}$ & $\mathrm{MgO}$ & Gph & Anhy & Arc & Syl & Cell & L-cys \\
\hline \multicolumn{18}{|c|}{ Rhizosphere } \\
\hline $25^{\circ} \mathrm{C}$ & $x$ & $x$ & $x$ & $x$ & $x$ & $x$ & & & & & & & & & & & $x$ \\
\hline $120^{\circ} \mathrm{C}$ & $x$ & $x$ & $x$ & $x$ & $x$ & & & & & & & & & & & & $x$ \\
\hline $300^{\circ} \mathrm{C}$ & $X$ & $x$ & $x$ & $X$ & $x$ & & & & & & & & & & & & \\
\hline $600^{\circ} \mathrm{C}$ & $x$ & $x$ & $x$ & $x$ & & & & $x$ & & & & & & & & & \\
\hline \multicolumn{18}{|l|}{ Ext. root } \\
\hline $25^{\circ} \mathrm{C}$ & $x$ & $x$ & & & & & & & & & & & & & & $x$ & \\
\hline $120^{\circ} \mathrm{C}$ & $x$ & $x$ & & & & & & & & & & & & & & $x$ & \\
\hline $300^{\circ} \mathrm{C}$ & $x$ & $x$ & & & & & & & & & & & & & & $x$ & \\
\hline $600^{\circ} \mathrm{C}$ & $x$ & $x$ & $x$ & & & & & & & $x$ & & $x$ & $x$ & & $x$ & & \\
\hline \multicolumn{18}{|l|}{ Int. root } \\
\hline $25^{\circ} \mathrm{C}$ & $x$ & $x$ & & & & & & & & & & & & & & $x$ & \\
\hline $120^{\circ} \mathrm{C}$ & $x$ & & & & & & & & & & & & & & & $x$ & \\
\hline $300^{\circ} \mathrm{C}$ & $X$ & $x$ & & & & & & & & & & & & & & $x$ & \\
\hline $600^{\circ} \mathrm{C}$ & $x$ & $x$ & $x$ & $x$ & & & & & $x$ & $x$ & & $x$ & & $x$ & $x$ & & \\
\hline \multicolumn{18}{|l|}{ Stem } \\
\hline $25^{\circ} \mathrm{C}$ & $x$ & & & $x$ & & & & & & & & & & & & $x$ & \\
\hline $120^{\circ} \mathrm{C}$ & $x$ & & & $X$ & & & & & & & & & & & & $X$ & \\
\hline $300^{\circ} \mathrm{C}$ & $x$ & & & & & & & & & & & $X$ & & & $x$ & $x$ & \\
\hline $600^{\circ} \mathrm{C}$ & $x$ & & $x$ & & & & & & $x$ & & $x$ & $x$ & & $X^{*}$ & $x$ & & \\
\hline
\end{tabular}

The rhizosphere unheated sample contains quartz, muscovite, and microcline which are considered as the main constituents of the bedrock, along with kaolinite, siderite, clinochlore, L-cysteine, and hydrozincite (Figure 4a) whose significance will be discussed in the Discussion. A better mineralogical characterization of phyllosilicates was obtained by XRD with longer acquisition times for the different granulometric fractions of rhizosphere, discriminated by wet gravity separation. These analyses confirm the presence of kaolinite in the clayey fraction and reveal the presence of clinochlore in the coarser one.

Heating at $120^{\circ} \mathrm{C}$ slightly modifies the intensity of several peaks of different phases, especially those of hydrozincite, producing the disappearance of the peak at $13.3^{\circ} 2 \theta$ and the decrease of the peak at $30.4^{\circ} 2 \theta$ (see zoom boxes in Figure $4 \mathrm{a}, \mathrm{b}$ ). At $300^{\circ} \mathrm{C}$ (Figure 4c), the L-cysteine and hydrozincite are completely degraded (no XRD features detected) while the other phases are still stable. At $600{ }^{\circ} \mathrm{C}$ (Figure $4 \mathrm{~d}$ ), the dehydroxylation of kaolinite occurs with the formation of metakaolin and at the same time the intensity of the 001 reflection of chlorite increases $\left(\approx 6.38^{\circ} 2 \theta\right)$. Microcline is replaced by its polymorph orthoclase, which is more stable at $600^{\circ} \mathrm{C}$ and the iron oxide $\left(\mathrm{Fe}_{2} \mathrm{O}_{3}\right)$ forms at the expense of siderite. Zincite $(\mathrm{ZnO})$, which commonly forms as a product of the thermal decomposition of hydrozincite, is not observed. 


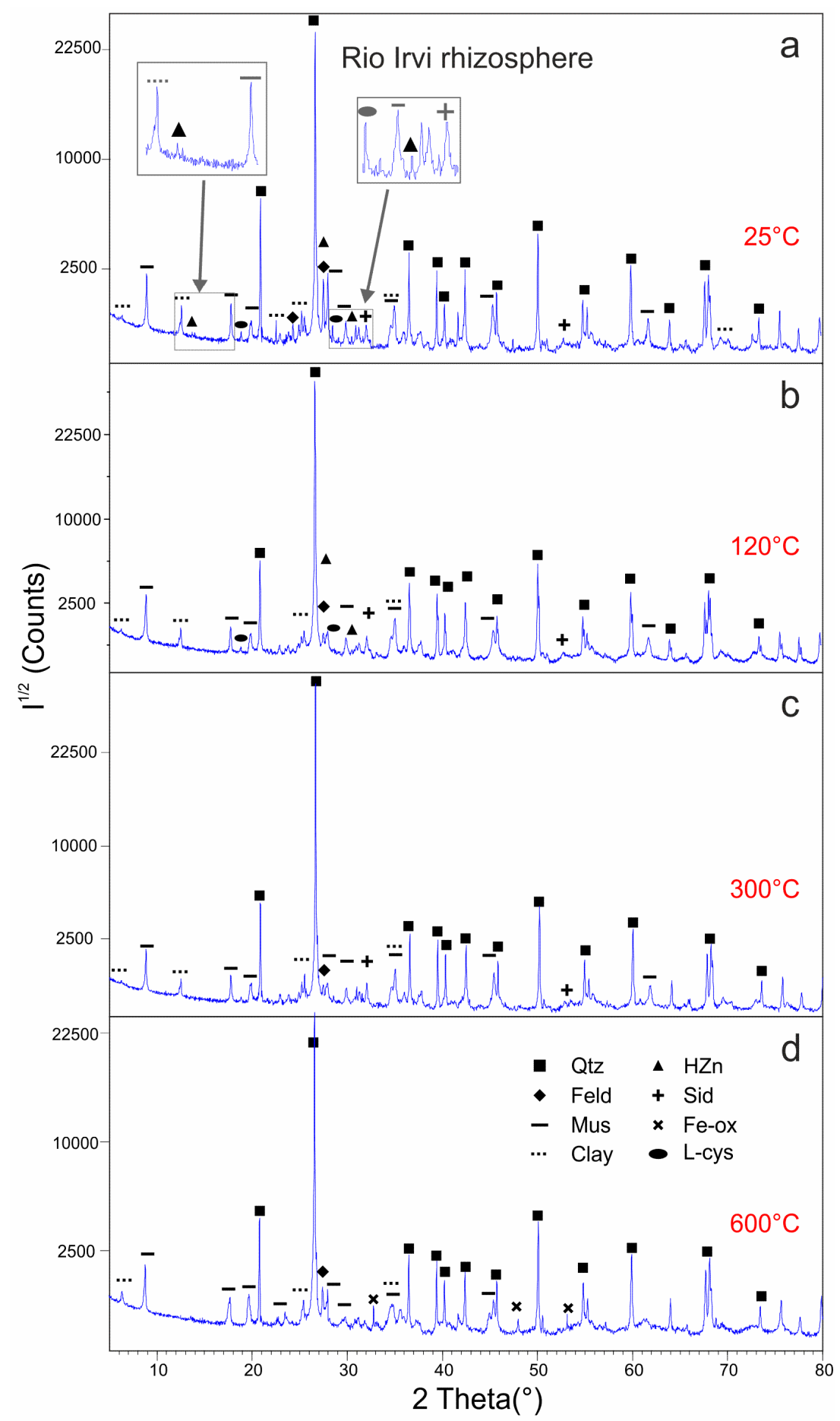

Figure 4. Comparison of X-ray Diffraction (XRD) patterns collected on rhizosphere from Rio Irvi before (a) and after ex-situ heating (b-d). Grey boxes in (a) show a close-up of the main hydrozincite peaks. Intensities $\left(\mathrm{I}^{1 / 2}\right)$ are reported in square root scale. Abbreviations as in Tables 2 and 3.

The external roots (Figure 5b), despite being previously washed with de-ionized water, show the peaks of quartz and muscovite, probably due to their strong adhesion to the roots. Furthermore, a poorly-defined, large peak ranging between $21-25^{\circ} 2 \theta$ testifies the presence of a poorly crystalline phase, likely an amorphous cellulose [53]. During the heating ramp (Table 2), cellulose signal tends to decrease. The first effect of heating (at $120^{\circ} \mathrm{C}$, Figure S1b) is the formation of some new peak that can be assigned to a muscovite polytype that disappears at $300^{\circ} \mathrm{C}$ (Figure S1c). XRD pattern after heating 
at $600{ }^{\circ} \mathrm{C}$ (Figure S1d) shows the lack of cellulose peaks due to its combustion and the formation of new phases such as calcium oxide $(\mathrm{CaO})$, carbon $(\mathrm{C})$, sylvite $(\mathrm{KCl})$, anhydrite $\left(\mathrm{CaSO}_{4}\right)$, and albite (Table 2$)$.

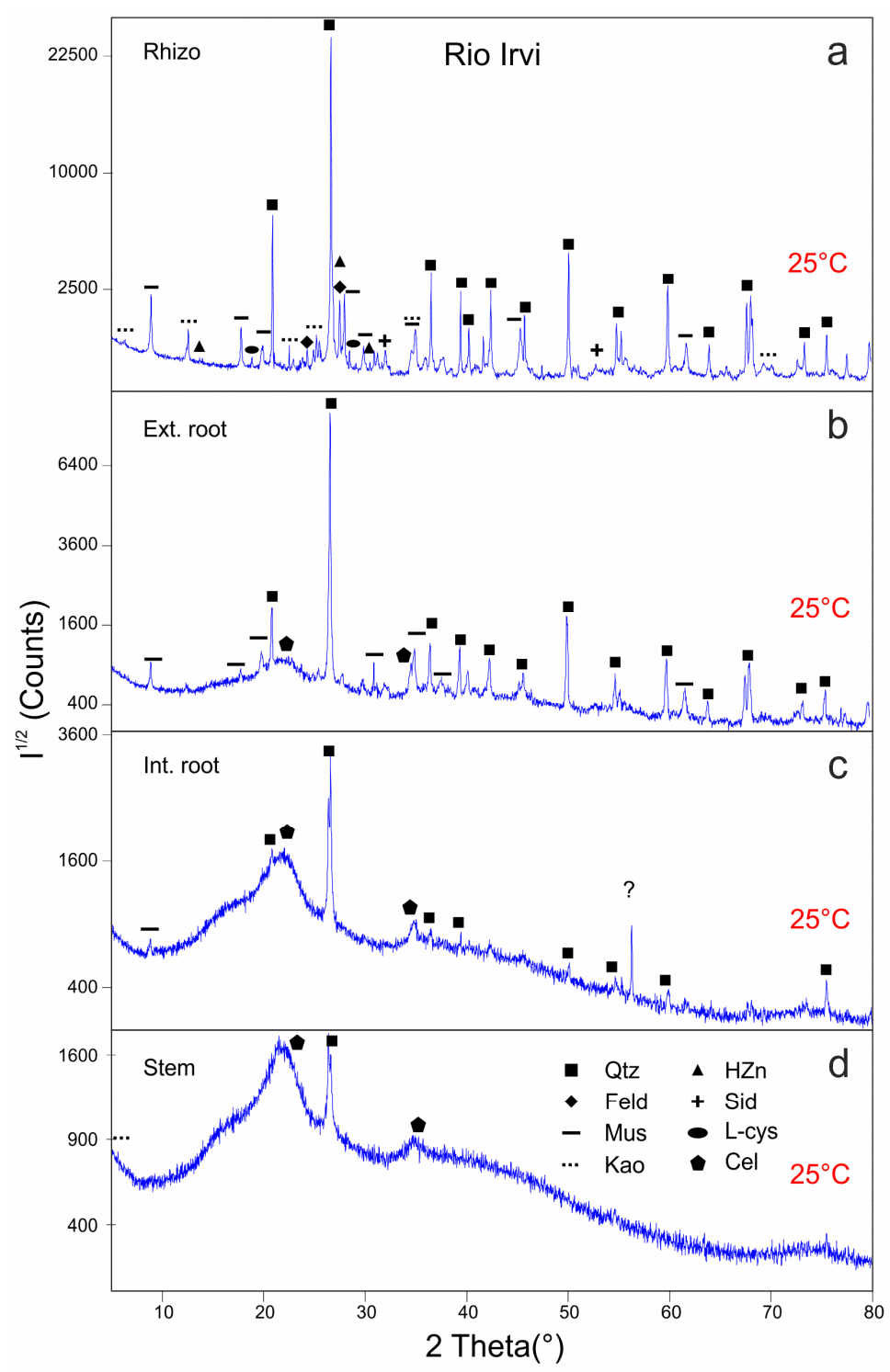

Figure 5. XRD patterns of samples from Rio Irvi collected before heating $\left(25^{\circ} \mathrm{C}\right)$ : rhizosphere (a), external root $(\mathbf{b})$, internal root $(\mathbf{c})$, and stem $(\mathbf{d})$. Intensities $\left(\mathrm{I}^{1 / 2}\right)$ are reported in a square root scale to highlight minor peaks. Abbreviations as in Tables 2 and 3. Question mark in (c) represents an unidentified peak probably due to an organic compound (see below).

XRD patterns of internal roots and stems (Figure 4c,d), as compared to rhizosphere and external root samples, are characterized by large, poorly-defined and less intense peaks due to the increase of cellulose content and to the reduced crystallinity of the mineral phases. In the internal root, as well as in the stems, quartz, cellulose, and muscovite are found. Other phases are not detected but could be masked by the relatively high noise and background levels. In the internal roots, an unassigned peak is found at about $56^{\circ} 2 \theta$ (Figure $5 \mathrm{c}$ ). It probably belongs to a hydrated phase or to an organic compound given that it disappears at $120^{\circ} \mathrm{C}$ (Figure S2b). At $600{ }^{\circ} \mathrm{C}$, cellulose is totally destroyed, and several symmetric small peaks are detected in both stem and internal root samples (Figures S2d and S3d). The former is characterized by very intense sylvite peaks and subordinate quartz, $\mathrm{MgO}$, arcanite/aphthitalite $\left(\left(\mathrm{K}_{2} \mathrm{SO}_{4} /(\mathrm{K}, \mathrm{Na})_{3} \mathrm{Na}\left(\mathrm{SO}_{4}\right)_{2}\right)\right.$, and willemite $\left(\mathrm{Zn}_{2} \mathrm{SiO}_{4}\right)$ (Table 2). The latter consists 
of quartz, arcanite, sylvite, willemite, and muscovite dehydroxylated having the strongest peak at $27.99^{\circ} 2 \theta[54]$.

\subsection{XRD Characterization of Rio Naracauli Samples}

Samples from the Rio Naracauli site were analyzed at room temperature and during in-situ heating at the MCX line of the Elettra synchrotron (Trieste, Italy). Mineral and organic compounds are summarized in Table 3. When performing these analyses, the thermogravimetric data were not yet acquired, thus the steps for the heating ramp were arbitrarily chosen as $200^{\circ} \mathrm{C}, 400{ }^{\circ} \mathrm{C}$, and $600^{\circ} \mathrm{C}$ for root samples (Figure S4a-d) and $400^{\circ}, 800^{\circ}$, and $1000^{\circ} \mathrm{C}$ for stem ones (Figure S4a-d). In order to compare Rio Irvi and Rio Naracauli XRD patterns, we emphasize that the X-ray wavelength used for synchrotron radiation XRD analysis was $\lambda=0.82594 \AA$ giving rise to a compression of about a factor 2 of the XRD patterns with respect to those measured in laboratory with the $\mathrm{Cu} K \alpha$ radiation $(\lambda=1.54056 \AA)$.

Table 3. Mineral assemblages of samples from Rio Naracauli at the different temperatures of the heating ramp. Abbreviation are: Qtz, quartz; Mus, muscovite; Feld, feldspars; Clay, clayey minerals; Gal, galena; Sph, sphalerite; Cer, cerussite; Pbj, plumbojarosite; Sid, siderite; Pyr, pyrite; $\mathrm{CaO}$, calcium oxide; Whe, whewellite; Cell, cellulose.

\begin{tabular}{|c|c|c|c|c|c|c|c|c|c|c|c|c|c|}
\hline Rio Naracauli & Qtz & Mus & Feld & Clay & Gal & Sph & Cer & $\mathrm{Pbj}$ & Sid & Pyr & $\mathrm{CaO}$ & Whe & Cell \\
\hline \multicolumn{14}{|l|}{ Rhizosphere } \\
\hline $25^{\circ} \mathrm{C}$ & $x$ & $x$ & & & $x$ & $x$ & $x$ & $x$ & $X$ & $x$ & & $x$ & \\
\hline \multicolumn{14}{|l|}{ External root } \\
\hline $25^{\circ} \mathrm{C}$ & $x$ & $x$ & & & $x$ & $x$ & $x$ & $X$ & $X$ & $x$ & & $x$ & $X$ \\
\hline $200^{\circ} \mathrm{C}$ & $X$ & $X$ & & $X$ & $X$ & $X$ & $X$ & $X$ & $X$ & $X$ & & $X$ & $X$ \\
\hline $400^{\circ} \mathrm{C}$ & $x$ & $x$ & $x$ & & $x$ & $x$ & $x$ & & $X$ & $x$ & & & $x$ \\
\hline $600^{\circ} \mathrm{C}$ & $x$ & $x$ & $x$ & $x$ & $x$ & $x$ & $x$ & & $X$ & $x$ & & & $x$ \\
\hline \multicolumn{14}{|l|}{ Internal root } \\
\hline $25^{\circ} \mathrm{C}$ & $x$ & & & & & & & & $X$ & & & & $x$ \\
\hline $200^{\circ} \mathrm{C}$ & $x$ & & & & & & & & $X$ & & & & $x$ \\
\hline $400^{\circ} \mathrm{C}$ & $x$ & & & & & & & & $X$ & & $x$ & & $x$ \\
\hline $600^{\circ} \mathrm{C}$ & $x$ & & & & & & & & & & $x$ & & $x$ \\
\hline \multicolumn{14}{|l|}{ Stem } \\
\hline $25^{\circ} \mathrm{C}$ & $x$ & & & & & & & & & & & & $x$ \\
\hline $400^{\circ} \mathrm{C}$ & $x$ & & & & & & & & & & & & $x$ \\
\hline $800^{\circ} \mathrm{C}$ & $x$ & & & & & & & & & & & & $x$ \\
\hline $1000^{\circ} \mathrm{C}$ & $x$ & & & & & & & & & & & & $x$ \\
\hline
\end{tabular}

The rhizosphere sample analyzed at room temperature shows a quite complex mineralogy formed by quartz, muscovite, and several phases linked to the mineralization as galena, sphalerite, cerussite, plumbojarosite, siderite, and pyrite (Figure 6a). Whewellite is likely present, as reported by Medas et al. [20], but its main peaks are juxtaposed to those of plumbojarosite leading to some uncertainty in peak attribution. Heating of this sample was not required because the organic matter was totally absent.

The mineral assemblage of the external roots is quite similar to that of the rhizosphere, but the main peaks of the minor phases are commonly less intense and less sharp (Figure 6b). The presence of cellulose or other similar organic compounds is highlighted by the increase of the background level and by a large hump between $11^{\circ}$ and $13^{\circ} 2 \theta$. 


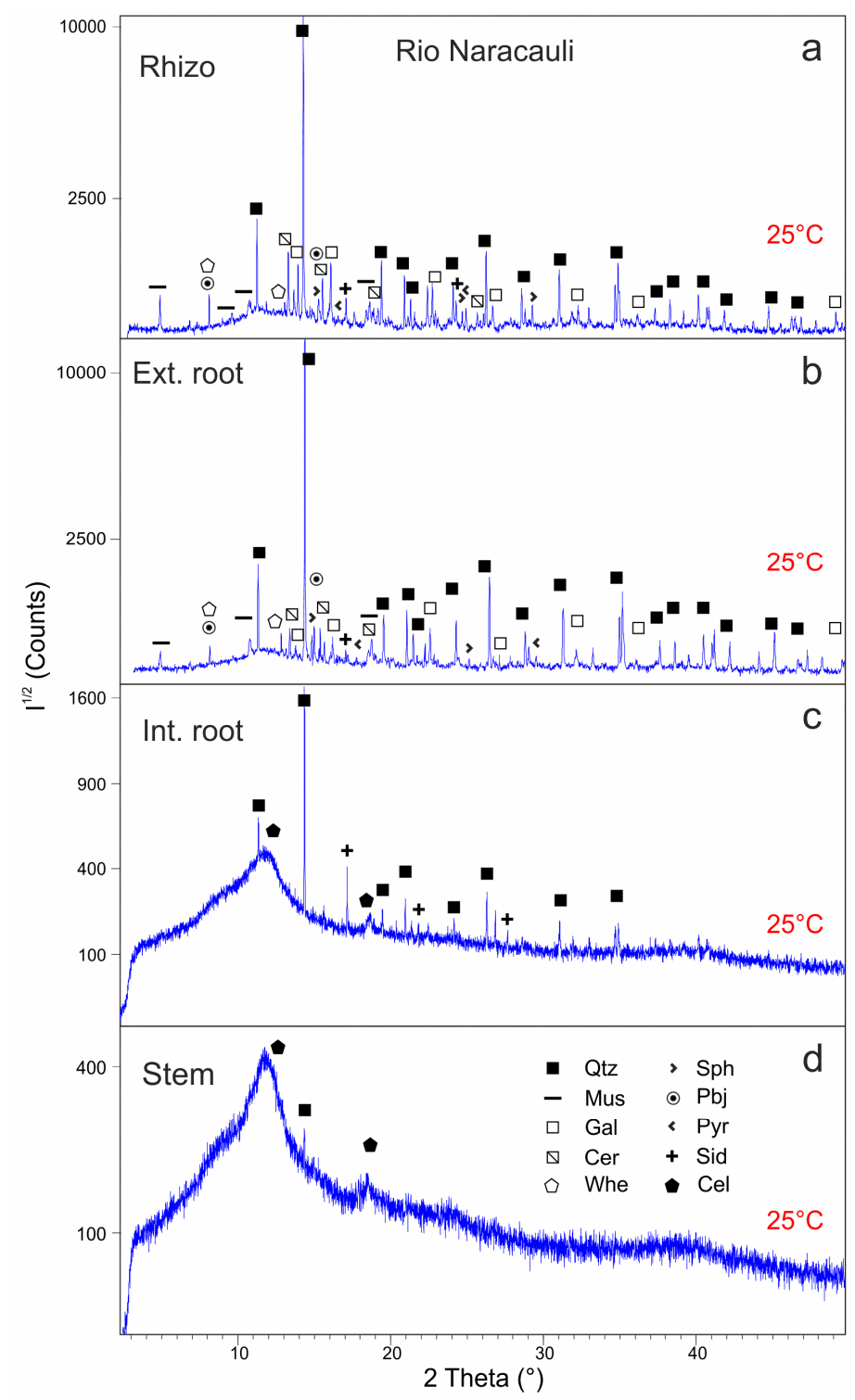

Figure 6. XRD patterns of samples from Rio Naracauli collected before heating $\left(25^{\circ} \mathrm{C}\right)$ : rhizosphere (a), external root (b), internal root $(\mathbf{c})$, and stem $(\mathbf{d})$. Intensities $\left(\mathrm{I}^{1 / 2}\right)$ are reported in a square root scale. Abbreviations as in Tables 2 and 3.

During the in-situ heating, quartz peaks become progressively more defined and tend to shift toward lower angles due to its thermal expansion. At $600^{\circ} \mathrm{C}$ (Figure S4d), the maximum shift of quartz peaks is reached $\left(0.13^{\circ} 2 \theta\right.$ for the (100) reflection and $0.17^{\circ} 2 \theta$ for the (101) one) and also their relative intensity is significantly modified with a marked increase of the reflections (100) at $11.1^{\circ}$ and (112) at $26.2^{\circ} 2 \theta$ and a slight decrease of the most intense one (101) at $14.2^{\circ} 2 \theta$. However, the transition from $\alpha-$ to $\beta$-quartz, commonly occurring around $573^{\circ} \mathrm{C}$, does not seem to be accomplished since it involves even higher deformations of lattice parameters that result in stronger shift of the peaks than those here observed [55]. Muscovite dehydroxylation occurs at $600^{\circ} \mathrm{C}$ and the intensity of the diffraction peaks are strongly modified. Pyrite and sphalerite crystallinity is enhanced with rising temperatures up to $400{ }^{\circ} \mathrm{C}$ (Figure S4c), as seen by their main reflections at $17.5^{\circ} 2 \theta$ for pyrite and $15.2^{\circ}$ and $25.0^{\circ} 2 \theta$ for sphalerite. Further temperature increase at $600^{\circ} \mathrm{C}$ produces the opposite effect, reducing the peak intensity to prior values. Plumbojarosite and whewellite are found up to $200^{\circ} \mathrm{C}$, while being totally lacking at $400{ }^{\circ} \mathrm{C}$, thus their stability is comprised in this temperature range. At the last temperature step $\left(600^{\circ} \mathrm{C}\right)$, two significant peaks, not detected before, are found at $7.5^{\circ}$ and $14.6^{\circ} 2 \theta$. They roughly 
correspond to albite major peaks, although shifted due to the thermal expansion. It is supported by the fact that albite has been found, at the same temperature, also in the external and internal roots of Rio Irvi.

In the internal roots (Figure $6 \mathrm{c}$ and Figure S5), the presence of cellulose is highlighted by the large "hump" between $10^{\circ}$ and $13^{\circ} 2 \theta$ and by the smaller, poor-defined peak at 17.5-18.5 $2 \theta$. Mineral phases are mainly quartz and siderite whose characteristic peak at $17^{\circ} 2 \theta$ is well defined. Residue peaks can be tentatively assigned to feldspars or hydrated sulfate like alunogen, but the high background produced by cellulose likely hide minor peaks of these phases impeding a precise attribution. Furthermore, is not unlikely the presence of clayey minerals or of whewellite [20], but their presence cannot be detected. The progressive heating of internal root samples does not reduce significantly the noise produced by cellulose, even at the maximum temperature. As observed in the external root samples, the heating produces a shift and the change of relative intensities of quartz reflections. In addition, the disappearance of siderite above $400{ }^{\circ} \mathrm{C}$, and the crystallization of small amounts of $\mathrm{CaO}$ are observed.

In the stem sample, cellulose and quartz can be detected at room temperature (Figure 6d). To reduce the noise of cellulose, a different heating ramp for the stem samples was chosen respect to the roots, increasing temperature at $400^{\circ}, 800^{\circ}$, and $1000^{\circ}$ (Figure S6). Nonetheless, this procedure failed in improving the signal, involving just an increase and a more marked shift of quartz peaks.

\section{Discussion}

The rhizosphere is the part of the soil ecosystem where plant roots, soil, and microorganisms interact with each other [56,57]. Here, the metabolic processes of roots create a peculiar physicochemical environment that often differs from that of the bulk soil [58,59]. Rhizosphere is characterized by the presence of several mineral and organic phases. In our study, quartz, phyllosilicates, feldspars, and ore-metal sulfides are probably inherited from the bedrock, whereas other phases are the product of biological and/or geochemical secondary processes. Heavy metal sulfates and carbonates result from the alteration and oxidation of the $\mathrm{Pb}-\mathrm{Zn}-\mathrm{Fe}$ mineralization as well as kaolinite results from feldspar weathering. Other minerals could derive from the biological activity within the rhizosphere i.e., hydrozincite, whose crystallization can be promoted by the activity of bacteria (Scytonema sp.) and microalgae (Chlorella sp.) [60,61]. Biologically-induced precipitation results in a poorly crystalline hydrozincite characterized by weak, broad, and shifted peaks $[62,63]$ as those observed in this study and detected with long acquisition times (about 8 hours). However, XRD data are not enough to state with certainty the biological origin of this mineral that could also precipitate by geochemical processes.

The presence of hydrozincite in rhizosphere samples of Juncus acutus from Rio Irvi is in agreement with the X-ray Absorption Near Edge Structure (XANES) data of Medas et al. [20]. According to these authors, about $50 \%$ of $\mathrm{Zn}$ is bound to hydrozincite, whereas the remaining part is distributed in $\mathrm{Zn}$ sulfate hydrate and in metal-organic compounds. This is probably the reason why such a significant amount of $\mathrm{Zn}(26,000 \mathrm{mg} / \mathrm{kg})$ is barely detected by XRD analyses. As reported in several occurrences [64], siderite also could be a product of bio-precipitation but, in this case, it is more likely a mineral belonging to the bedrock given that it is quite common in the gangue of the study area. The biological and chemical activity of rhizosphere is further testified by the presence of L-cysteine root exudate $[65,66]$, an amino acid synthesized by plants for detoxification [67] and immunity by pathogens $[68,69]$.

The first effect of rhizosphere heating is the decomposition of L-cysteine and hydrozincite before $300{ }^{\circ} \mathrm{C}$. Total decomposition of L-cysteine at $300{ }^{\circ} \mathrm{C}$ is in agreement with previous studies [70,71] and it is preceded by the release of volatile compounds starting from $200{ }^{\circ} \mathrm{C}$ [72]. Hydrozincite as well, is reported to decompose in the $220-250{ }^{\circ} \mathrm{C}$ temperature range $[73,74]$, resulting in zincite crystallization. In this case, neither zincite nor other $\mathrm{Zn}$ phases are observed after the hydrozincite decomposition, even at $600{ }^{\circ} \mathrm{C}$. Siderite decomposition commonly starts above $450{ }^{\circ} \mathrm{C}[75]$ but the particle size or the chemical composition can significantly modify this temperature [76]. In this case study, siderite is still stable at $300^{\circ} \mathrm{C}$ and becomes unstable at $600^{\circ} \mathrm{C}$, temperature at which iron oxide 
was found. This latter is probably attributable to a siderite thermal decomposition product and as a result of dehydroxylation of amorphous goethite, commonly found in the soil of studied area. Other significant changes occur over $600{ }^{\circ} \mathrm{C}$ : the disappearance of the strongest kaolinite peak at about $12.5^{\circ} 2 \theta$, due to its dehydroxylation $[77,78]$; the intensity increase of a peak at $6.4^{\circ} 2 \theta$, that could be related to clinochlore crystallization; and finally, the slight shift of K-feldspar peaks which suggest the microcline-orthoclase transformation.

The external roots from the two sites show a mineral assemblage similar to that of the corresponding rhizosphere. Maybe, these minerals were incorporated into the organic tissues during the plant growth as observed by [30]. In both XRD patterns, the cellulose signal is detected. The pattern of cellulose here reported seems to suggest the presence of both microcrystalline and amorphous cellulose or of a polymer with intermediate crystallographic properties. Indeed, all the main peaks of microcrystalline cellulose are found but their base widths and their intensities can be compared with those of the amorphous phase [53]. In particular, the two peaks at $15.02^{\circ}$ and $16.49^{\circ} 2 \theta$ are here observed as a poorly defined "humps" comprised in a $2 \theta$ range of $14.5-17.5^{\circ}$ (with $\mathrm{CuK} \alpha$ beam).

External root samples show a different behavior under ex-situ and in-situ heating (Figure 7a,b). In the first case, no significant changes occur until the last stage $\left(600^{\circ} \mathrm{C}\right)$ at which the organic compounds are totally destroyed and new phases are detected: carbon as product of cellulose combustion, $\mathrm{CaO}$ and anhydrite resulting from calcination and dehydration of the Ca-bearing phases, sylvite and plagioclase. On the contrary, in-situ heating produces only minor changes suggesting that: (i) the capillary sample holder does not allow the air flux and thus the combustion and the dehydration of the sample; (ii) the cooling down procedure in ex-situ experiments, not occurring in in-situ ones, could have a role that should be considered. The main effect revealed by in-situ measurements is the plumbojarosite and whewellite disappearance. The latter is one of the most common phases in plants tissues, commonly occurring within the cells but also in extracellular form $[79,80]$. Whewellite is stable up to $400{ }^{\circ} \mathrm{C}$ as already reported by Quintana et al. [81] and above this temperature it decomposes, probably forming calcite $[82,83]$. Further temperature increases result in the appearance of two small unassigned peaks, but expected reactions as cellulose combustion or sulfides oxidation do not occur.

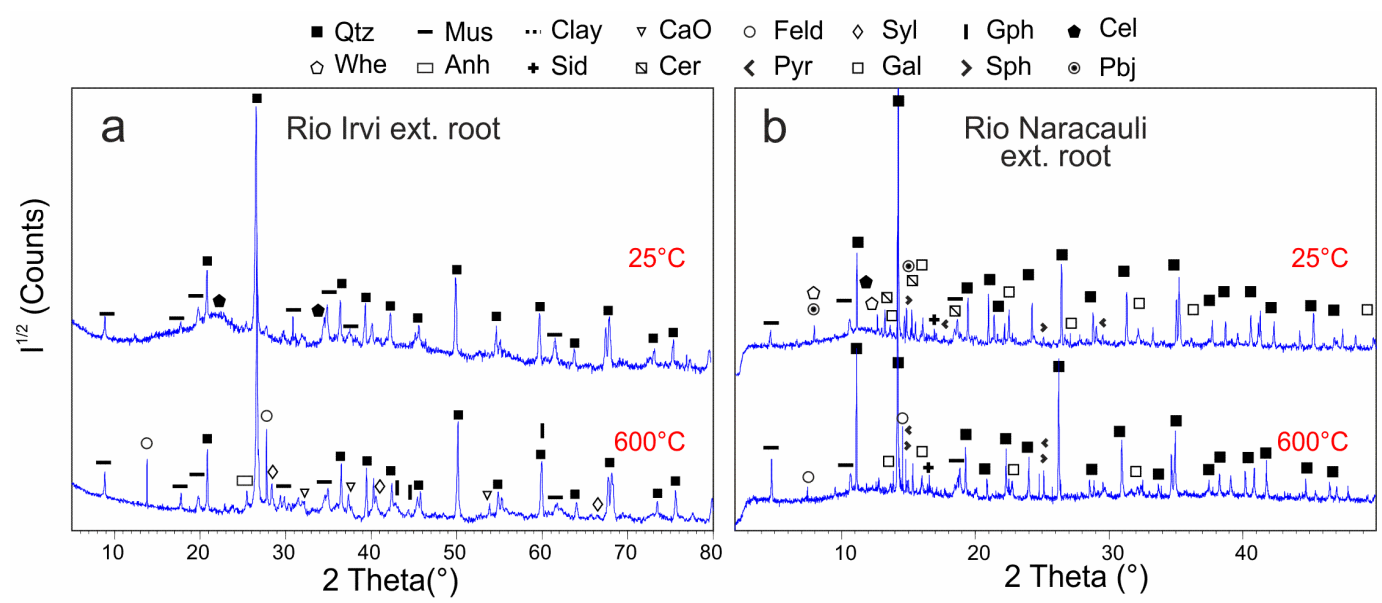

Figure 7. XRD patterns showing the effect of ex-situ heating on external root samples from Rio Irvi (a) and in-situ heating on external root samples from Rio Naracauli $(\mathbf{b})$. Intensities $\left(\mathrm{I}^{1 / 2}\right)$ are reported in a square root scale. Abbreviations as in Tables 2 and 3.

In the internal root and in the stem the main compound is the cellulose but also quartz and muscovite are commonly detected. At room temperature, no crystalline metal-bearing phases were found, probably because the metals are bound to organic ligands $[35,36]$ or are in amorphous phases. Plant tissues react in different ways to the ex-situ or in-situ heating (Figure 8a,b). The latter does not produce significant changes even at temperature as high as $1000^{\circ} \mathrm{C}$ at which cellulose background is slightly reduced but not enough to observe the reflections relative to minor minerals. The former 
produces the first changes since the first steps of heating ramp as the disappearance of a peak at $56^{\circ} 2 \theta$ (probably related to a hydrated phase) and the formation of sylvite and graphite at $300{ }^{\circ} \mathrm{C}$. After heating at $600{ }^{\circ} \mathrm{C}$, cellulose is totally destroyed and new K-bearing phases, i.e., arcanite $\left(\mathrm{K}_{2} \mathrm{SO}_{4}\right)$ and sylvite $(\mathrm{KCl})$ crystallize probably at the expense of the potash hosted in organic tissues. Feldspars also are found and are revealed by different peaks in the $27-28^{\circ} 2 \theta$ range. Plagioclase, together with sylvite and arcanite has been reported from pyrolysis of organic wastes aimed to convert them in biochar $[84,85]$. Furthermore, at $600{ }^{\circ} \mathrm{C}$, willemite $\left(\mathrm{Zn}_{2} \mathrm{SiO}_{4}\right)$ is observed in roots and stems whereas calcium and magnesium oxides are detected only in the stem. Although no $\mathrm{Zn}$ phases were detected before heating, and it is known that Juncus acutus is not a $\mathrm{Zn}$ accumulator plant because it tends to concentrate $\mathrm{Zn}$ in the root epidermis [20], the presence of willemite is not unlikely. Chemical analysis show $\mathrm{Zn}$ concentrations of $9700 \mathrm{mg} / \mathrm{kg}$ in the internal root and $1800 \mathrm{mg} / \mathrm{kg}$ in the stem so, considering that after heating at $600{ }^{\circ} \mathrm{C}$ about $95 \%$ of the initial mass is loss, it is not surprising to detect traces of $\mathrm{Zn}$ phases in the combustion products. The appearance of willemite after heating is in agreement with the stability of this phase at temperatures higher than $250{ }^{\circ} \mathrm{C}$ (at room pressure), whereas at lower temperatures hydrated $\mathrm{Zn}$ silicates such as sauconite $\left(\mathrm{Zn}_{3} \mathrm{Si}_{4} \mathrm{O}_{10}(\mathrm{OH})_{2} \cdot \mathrm{nH}_{2} \mathrm{O}\right)$ or hemimorphite $\left(\mathrm{Zn}_{4}(\mathrm{OH})_{2} \mathrm{Si}_{2} \mathrm{O}_{7} \cdot \mathrm{H}_{2} \mathrm{O}\right)$ are more stable $[86,87]$.

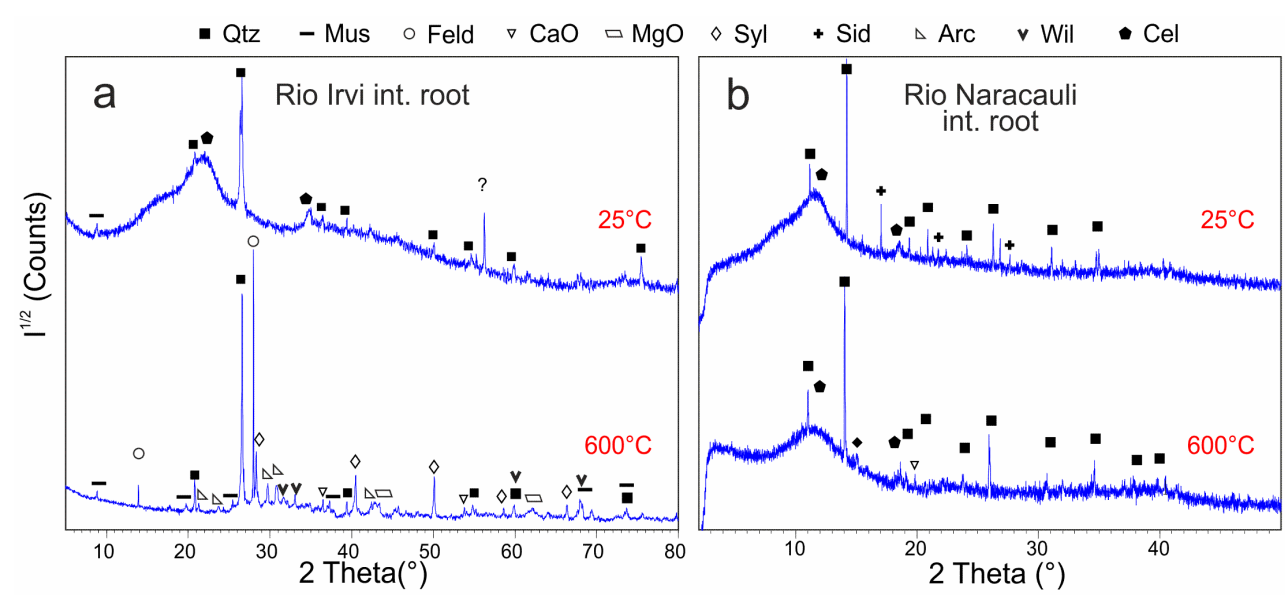

Figure 8. XRD patterns showing the effect of ex-situ heating on internal root samples from Rio Irvi (a) and in-situ heating on internal root samples from Rio Naracauli $(\mathbf{b})$. Intensities $\left(\mathrm{I}^{1 / 2}\right)$ are reported in a square root scale. Abbreviations as in Tables 2 and 3.

As mentioned above, the thermal treatment of biomasses is widely studied to evaluate their potential in phytomining [37,38], and to optimize the production of biochar $[32,39]$ and biofuel $[88,89]$. Ecological outcomes vary from the amendment/bioremediation effect onto the soil [33,90-92], to the $\mathrm{CO}_{2}$ sequestration $[93,94]$, to the energy saving resulting from the use of these renewable sources [84], and to the metal recovery [37].

The chemical, physical, and mineralogical features of the pyrolyzed or combusted biomasses, and thus their efficiency, are mainly controlled by the treatment conditions (temperature, heating rate, duration, and gas/water presence) and by the starting material $[39,95]$. For this reason, several papers report detailed characterization of biomasses before and after thermal treatment, but few of them highlight the great relevance of the mineralogical composition. As reported by Vassilev et al. [96] (and references therein), great interest is focused on the chemical composition of biomasses but less attention is paid to the specific phases and minerals. The knowledge of the latter is essential to assess the bioavailability of nutrients [97] and the metal removal capacity of biochar [98], as well as for the metal recovery from biomass ashes [99] (and references therein). Furthermore, the influence of mineral phases content in biomass ashes has been related to the efficiency and to the various technical issues occurring in power plants that use this kind of fuel [100]. 


\section{Conclusions}

In this work, we presented not only a specific case study of plant/soil interaction in an abandoned mine area contaminated by metals, but also a methodology that could be applied elsewhere.

The ex-situ heating turned out to be a useful tool in determining the occurrence of metal-bearing phases in plants, reducing or even removing the high background noise level produced by amorphous or low crystalline organic compounds and thus allowing to: (i) recognize minor minerals already present in the samples but previously hidden or barely recognizable and (ii) crystallize new phases reflecting the chemical composition of the samples. This procedure, could be very effective when more sophisticated analytical techniques are not available, especially if combined with thermal analyses in order to reveal the temperature stages at which the significant reactions occur. Indeed, too low temperatures do not allow the development of phase transitions and the decomposition of organic compounds, whereas too high temperatures should lead to the decomposition of the new crystallizing phases before they are detected.

On the contrary, the in-situ high temperature synchrotron-based XRD analyses are more sensitive for revealing very minor phases in mainly-inorganic samples (i.e., soil and rhizosphere), but they are less effective in organic matter-rich ones. Indeed, the in-situ heating failed in improving the quality of signal because, even at extremely high temperature, the organic matter was not destroyed. The absence of oxygen within the capillary sample holder does not allow the cellulose combustion and also impedes the sulfides oxidation. In addition, the shift observed in the XRD patterns, due to the thermal expansion, make it difficult to interpret the peaks. Indeed, each mineral has a different coefficient of thermal expansion and even the same mineral, if not isotropic, is affected by differential expansions.

Further developments of this technique should be aimed at obtaining a more precise attribution of all peaks, for instance by coupling synchrotron XRD analysis of ex-situ heated samples with micro-XRF mapping. A development of this kind of analysis could improve our understanding of the interaction between plants and soil and could also have practical application. The potential recovery of metals by hyper-accumulator plants, that is the object of several studies, could benefit from XRD analysis combined with thermal treatment aimed at discover which temperatures lead to the crystallization of mineral phases more suitable for exploitation. Another potential application of these combined techniques is the production of biochar from vegetal masses. In this case, it is also required to know the optimum temperatures to obtain minerals that easily decompose and make bioavailable their chemical constituents.

Supplementary Materials: The following are available online at http://www.mdpi.com/1660-4601/16/11/1976/s1.

Author Contributions: Conceptualization, G.D.G.; validation, D.M.; formal analysis, D.F., J.S., D.M., E.R., and A.M.; investigation, J.S. and C.M.; data curation, D.F., J.S., D.M., E.R., and A.M.; writing一 original draft preparation, D.F.; writing-review and editing, D.F., D.M., E.R., A.M., C.M., and G.D.G.; visualization, D.F.; supervision, D.M., E.R., A.M., and G.D.G.; project administration, G.D.G.; funding acquisition, C.M. and G.D.G.

Funding: The authors acknowledge CESA (grant number: E58C16000080003) from RAS and RAS/FBS (grant number: F72F16003080002) grants, and FP7 ERANETMED2 72094 SUPREME. MCX (Elettra) 20140061 beamtime is acknowledged. CM acknowledges the Grant of Excellence Departments, MIUR (ARTICOLO 1, COMMI 314-337 LEGGE 232/2016).

Acknowledgments: Authors acknowledge Salvatore Vacca from the Department of Chemical and Geological Science, University of Cagliari, for his precious help with the wet gravity separation method, and MCX (Elettra) 20140061 beamtime.

Conflicts of Interest: The authors declare no conflict of interest.

\section{References}

1. Kopittke, P.M.; Gianoncelli, A.; Kourousias, G.; Green, K.; McKenna, B.A. Alleviation of Al Toxicity by Si Is Associated with the Formation of Al-Si Complexes in Root Tissues of Sorghum. Front. Plant Sci. 2017, 8, 2189:1-2189:9. [CrossRef] [PubMed] 
2. Gall, J.E.; Boyd, R.S.; Rajakaruna, N. Transfer of heavy metals through terrestrial food webs: A review. Environ. Monit. Assess. 2015, 187, 201. [CrossRef]

3. Salt, D.E.; Blaylock, M.; Kumar, N.P.B.A.; Dushenkov, V.; Ensley, B.D.; Chet, I.; Raskin, I. Phytoremediation: A novel strategy for the removal of toxic metals from the environment using plants. Bio/Technology 1995, 13, 468-474. [CrossRef] [PubMed]

4. Pulford, I.D.; Watson, C. Phytoremediation of heavy metal-contaminated land by trees-A review. Environ. Int. 2003, 29, 529-540. [CrossRef]

5. Ghosh, M.; Singh, S.P. Asian Journal on Energy and Environment A Review on Phytoremediation of Heavy Metals and Utilization of It's by Products. Asian J. Energy Environ. 2005, 6, 214-231.

6. Ali, H.; Khan, E.; Sajad, M.A. Phytoremediation of heavy metals-Concepts and applications. Chemosphere 2013, 91, 869-881. [CrossRef]

7. Mahar, A.; Wang, P.; Ali, A.; Awasthi, M.K.; Lahori, A.H.; Wang, Q.; Li, R.; Zhang, Z. Challenges and opportunities in the phytoremediation of heavy metals contaminated soils: A review. Ecotoxicol. Environ. Saf. 2016, 126, 111-121. [CrossRef]

8. Verma, P.; George, K.V.; Singh, H.V.; Singh, S.K.; Juwarkar, A.; Singh, R.N. Modeling rhizofiltration: Heavy-metal uptake by plant roots. Environ. Model. Assess. 2006, 11, 387-394. [CrossRef]

9. Mendez, M.O.; Glenn, E.P.; Maier, R.M. Phytostabilization Potential of Quailbush for Mine Tailings. J. Environ. Qual. 2007, 36, 245-253. [CrossRef]

10. Bhargava, A.; Carmona, F.F.; Bhargava, M.; Srivastava, S. Approaches for enhanced phytoextraction of heavy metals. J. Environ. Manag. 2012, 105, 103-120. [CrossRef]

11. Limmer, M.; Burken, J. Phytovolatilization of Organic Contaminants. Environ. Sci. Technol. 2016, 50, 6632-6643. [CrossRef] [PubMed]

12. LeFevre, G.H.; Müller, C.E.; Li, R.J.; Luthy, R.G.; Sattely, E.S. Rapid Phytotransformation of Benzotriazole Generates Synthetic Tryptophan and Auxin Analogs in Arabidopsis. Environ. Sci. Technol. 2015, 49, 10959-10968. [CrossRef] [PubMed]

13. Du Laing, G.; Van de Moortel, A.M.K.; Moors, W.; De Grauwe, P.; Meers, E.; Tack, F.M.G.; Verloo, M.G. Factors affecting metal concentrations in reed plants (Phragmites australis) of intertidal marshes in the Scheldt estuary. Ecol. Eng. 2009, 35, 310-318. [CrossRef]

14. Anton, A.; Mathe-Gaspar, G. Factors affecting heavy metal uptake in plant selection for phytoremediation. $Z$. Naturforsch. C 2005, 60, 244-246. [PubMed]

15. Chehregani, A.; Noori, M.; Yazdi, H.L. Phytoremediation of heavy-metal-polluted soils: Screening for new accumulator plants in Angouran mine (Iran) and evaluation of removal ability. Ecotoxicol. Environ. Saf. 2009, 72, 1349-1353. [CrossRef]

16. Barbafieri, M.; Dadea, C.; Tassi, E.; Bretzel, F.; Fanfani, L. Uptake of Heavy Metals by Native Species Growing in a Mining Area in Sardinia, Italy: Discovering Native Flora for Phytoremediation. Int. J. Phytoremediation 2011, 13, 985-997. [CrossRef]

17. Kim, S.; Lim, H.; Lee, I. Enhanced heavy metal phytoextraction by Echinochloa crus-galli using root exudates. J. Biosci. Bioeng. 2010, 109, 47-50. [CrossRef]

18. Turnau, K.; Ryszka, P.; Wojtczak, G. Metal Tolerant Mycorrhizal Plants: A Review from the Perspective on Industrial Waste in Temperate Region. In Arbuscular Mycorrhizas: Physiology and Function; Springer: Dordrecht, The Netherlands, 2010; pp. 257-276.

19. Bonfante, P.; Anca, I.-A. Plants, Mycorrhizal Fungi, and Bacteria: A Network of Interactions. Annu. Rev. Microbiol. 2009, 63, 363-383. [CrossRef]

20. Medas, D.; De Giudici, G.; Pusceddu, C.; Casu, M.A.; Birarda, G.; Vaccari, L.; Gianoncelli, A.; Meneghini, C. Impact of Zn excess on biomineralization processes in Juncus acutus grown in mine polluted sites. J. Hazard. Mater. 2019, 370, 98-107. [CrossRef]

21. Boi, M.E.; Medas, D.; Bacchetta, G.; Cappai, G.; Carlomagno, I.; Casu, M.A.; Gianoncelli, A.; Meneghini, C.; Piredda, M.; Podda, F.; et al. Biomineral formation in the soil-plant system in metal-extreme environments: An investigation of Helichrysum microphyllum Cambess. subsp. tyrrhenicum, in press.

22. Chibuike, G.U.; Obiora, S.C. Heavy metal polluted soils: Effect on plants and bioremediation methods. Appl. Environ. Soil Sci. 2014, 2014. [CrossRef]

23. Bani, A.; Echevarria, G.; Sulçe, S.; Morel, J.L. Improving the Agronomy of Alyssum murale for Extensive Phytomining: A Five-Year Field Study. Int. J. Phytoremediation 2015, 17, 117-127. [CrossRef] [PubMed] 
24. Rascio, N.; Navari-Izzo, F. Heavy metal hyperaccumulating plants: How and why do they do it? And what makes them so interesting? Plant Sci. 2011, 180, 169-181. [CrossRef] [PubMed]

25. St-Cyr, L.; Campbell, P.C. Metals (Fe, Mn, Zn) in the root plaque of submerged aquatic plants collected in situ: Relations with metal concentrations in the adjacent sediments and in the root tissue. Biogeochemistry 1996, 33, 45-76. [CrossRef]

26. De Giudici, G.; Pusceddu, C.; Medas, D.; Meneghini, C.; Gianoncelli, A.; Rimondi, V.; Podda, F.; Cidu, R.; Lattanzi, P.; Wanty, R.B.; et al. The role of natural biogeochemical barriers in limiting metal loading to a stream affected by mine drainage. Appl. Geochem. 2017, 76, 124-135. [CrossRef]

27. Shankramma, K.; Yallappa, S.; Shivanna, M.B.; Manjanna, J. Fe2O3 magnetic nanoparticles to enhance $S$. lycopersicum (tomato) plant growth and their biomineralization. Appl. Nanosci. 2016, 6, 983-990. [CrossRef]

28. Vittori Antisari, L.; Carbone, S.; Gatti, A.; Vianello, G.; Nannipieri, P. Uptake and translocation of metals and nutrients in tomato grown in soil polluted with metal oxide $\left(\mathrm{CeO}_{2}, \mathrm{Fe}_{3} \mathrm{O}_{4}, \mathrm{SnO}_{2}, \mathrm{TiO}_{2}\right)$ or metallic $(\mathrm{Ag}, \mathrm{Co}$, Ni) engineered nanoparticles. Environ. Sci. Pollut. Res. 2015, 22, 1841-1853. [CrossRef] [PubMed]

29. Medas, D.; De Giudici, G.; Casu, M.A.; Musu, E.; Gianoncelli, A.; Iadecola, A.; Meneghini, C.; Tamburini, E.; Sprocati, A.R.; Turnau, K.; et al. Microscopic processes ruling the bioavailability of Zn to roots of Euphorbia Pithyusa L. Pioneer plant. Environ. Sci. Technol. 2015, 49, 1400-1408. [CrossRef] [PubMed]

30. De Giudici, G.; Medas, D.; Meneghini, C.; Casu, M.A.; Gianoncelli, A.; Iadecola, A.; Podda, S.; Lattanzi, P. Microscopic biomineralization processes and Zn bioavailability: A synchrotron-based investigation of Pistacia lentiscus L. roots. Environ. Sci. Pollut. Res. 2015, 22, 19352-19361. [CrossRef] [PubMed]

31. Mateos-Naranjo, E.; Castellanos, E.M.; Perez-Martin, A. Zinc tolerance and accumulation in the halophytic species Juncus acutus. Environ. Exp. Bot. 2014, 100, 114-121. [CrossRef]

32. Zheng, H.; Wang, Z.; Deng, X.; Zhao, J.; Luo, Y.; Novak, J.; Herbert, S.; Xing, B. Characteristics and nutrient values of biochars produced from giant reed at different temperatures. Bioresour. Technol. 2013, 130, 463-471. [CrossRef] [PubMed]

33. Xing, Y.; Wang, J.; Xia, J.; Liu, Z.; Zhang, Y.; Du, Y.; Wei, W. A pilot study on using biochars as sustainable amendments to inhibit rice uptake of $\mathrm{Hg}$ from a historically polluted soil in a Karst region of China. Ecotoxicol. Environ. Saf. 2019, 170, 18-24. [CrossRef]

34. Curie, C.; Briat, J.-F. Iron Transport and Signaling in Plants. Annu. Rev. Plant Biol. 2003, 54, $183-206$. [CrossRef] [PubMed]

35. Pourrut, B.; Shahid, M.; Dumat, C.; Winterton, P.; Pinelli, E. Lead uptake, toxicity, and detoxification in plants. Rev. Environ. Contam. Toxicol. 2011, 213, 113-136. [CrossRef] [PubMed]

36. Broadley, M.R.; White, P.J.; Hammond, J.P.; Zelko, I.; Lux, A. Zinc in plants. New Phytol. 2007, 173, 677-702. [CrossRef] [PubMed]

37. Lievens, C.; Yperman, J.; Vangronsveld, J.; Carleer, R. Study of the potential valorisation of heavy metal contaminated biomass via phytoremediation by fast pyrolysis: Part I. Influence of temperature, biomass species and solid heat carrier on the behaviour of heavy metals. Fuel 2007. [CrossRef]

38. Zhang, X.; Houzelot, V.; Bani, A.; Morel, J.L.; Echevarria, G.; Simonnot, M.-O. Selection and Combustion of Ni-Hyperaccumulators for the Phytomining Process. Int. J. Phytoremediation 2014, 16, 1058-1072. [CrossRef]

39. Kloss, S.; Zehetner, F.; Dellantonio, A.; Hamid, R.; Ottner, F.; Liedtke, V.; Schwanninger, M.; Gerzabek, M.H.; Soja, G. Characterization of Slow Pyrolysis Biochars: Effects of Feedstocks and Pyrolysis Temperature on Biochar Properties. J. Environ. Qual. 2012, 41, 990. [CrossRef] [PubMed]

40. Syranidou, E.; Christofilopoulos, S.; Kalogerakis, N. Juncus spp.-The helophyte for all (phyto)remediation purposes? N. Biotechnol. 2017, 38, 43-55. [CrossRef]

41. Christofilopoulos, S.; Syranidou, E.; Gkavrou, G.; Manousaki, E.; Kalogerakis, N. The role of halophyte Juncus acutus L. in the remediation of mixed contamination in a hydroponic greenhouse experiment. J. Chem. Technol. Biotechnol. 2016, 91, 1665-1674. [CrossRef]

42. Piano Regionale Di Gestione Dei Rifiuti-Piano Di Bonifica Dei Siti Inquinati; R.A.S. Report; The Royal Astronomical Society: London, UK, 2003.

43. Cuccuru, S.; Naitza, S.; Secchi, F.; Puccini, A.; Casini, L.; Pavanetto, P.; Linnemann, U.; Hofmann, M.; Oggiano, G. Structural and metallogenic map of late Variscan Arbus Pluton (SW Sardinia, Italy). J. Maps 2016, 12, 860-865. [CrossRef] 
44. Secchi, F.A.; Brotzu, P.; Callegari, E. The Arburese igneous complex (SW Sardinia, Italy)—An example of dominant igneous fractionation leading to peraluminous cordierite-bearing leucogranites as residual melts. Chem. Geol. 1991, 92, 213-249. [CrossRef]

45. De Giudici, G.; Medas, D.; Cidu, R.; Lattanzi, P.; Podda, F.; Frau, F.; Rigonat, N.; Pusceddu, C.; Da Pelo, S.; Onnis, P.; et al. Application of hydrologic-tracer techniques to the Casargiu adit and Rio Irvi (SW-Sardinia, Italy): Using enhanced natural attenuation to reduce extreme metal loads. Appl. Geochem. 2008, 96, 42-54. [CrossRef]

46. Frau, F.; Medas, D.; Da Pelo, S.; Wanty, R.B.; Cidu, R. Environmental effects on the aquatic system and metal discharge to the mediterranean sea from a near-neutral zinc-ferrous sulfate mine drainage. Water. Air. Soil Pollut. 2015, 226, 226-255. [CrossRef]

47. Medas, D.; Cidu, R.; De Giudici, G.; Podda, F. Chemical data on environmental matrices from an abandoned mining site. Data Br. 2019, 23. [CrossRef]

48. Cao Pinna, C.; Silvano, R.; Fadda, A.; Buffa, F.; Orrù, N. Studio dell'Idrologia Superficiale della Sardegna (SISS); EAF (Ente Autonomo del Flumendosa): Cagliari, Italy, 1998.

49. Rebuffi, L.; Plaisier, J.R.; Abdellatief, M.; Lausi, A.; Scardi, A.P. Mcx: A synchrotron radiation beamline for X-ray diffraction line profile analysis. Z. Anorg. Allg. Chem. 2014, 640, 3100-3106. [CrossRef]

50. Riello, P.; Lausi, A.; Macleod, J.; Plaisier, J.R.; Zerauschek, G.; Fornasiero, P. In situ reaction furnace for real-time XRD studies. J. Synchrotron Radiat. 2013, 20, 194-196. [CrossRef]

51. Hammersley, A.P.; Svensson, S.O.; Hanfland, M.; Fitch, A.N.; Hausermann, D. Two-dimensional detector software: From real detector to idealised image or two-theta scan. High Press. Res. 1996, 14, 235-248. [CrossRef]

52. Kourkoumelis, N. PowDLL, a reusable .NET component for interconverting powder diffraction data: Recent developments. Powder Diffr. 2013, 28, 137-148.

53. Ciolacu, D.; Ciolacu, F.; Popa, V.I. Amorphous cellulose-Structure and characterization. Cellul. Chem. Technol. 2011, 45, 13-21.

54. Guggenheim, S.; Chang, Y.-H.; Koster Van Groos, A.F. Muscovite dehydroxylation: High-temperature studies. Am. Mineral. 1987, 72, 537-550.

55. Ackermann, R.J.; Sorrell, C.A. Thermal expansion and the high-low transformation in quartz. I. High-Temperature X-ray Studies*. J. Appl. Crystallogr. 1974, 7, 461-467. [CrossRef]

56. Lynch, J.M.; de Leij, F. Rhizosphere. In eLS; John Wiley \& Sons, Ltd.: Chichester, UK, 2012.

57. Shelef, O.; Hahn, P.G.; Getman-Pickering, Z.; Martinez Medina, A. Coming to Common Ground: The Challenges of Applying Ecological Theory Developed Aboveground to Rhizosphere Interactions. Front. Ecol. Evol. 2019, 7, 58. [CrossRef]

58. Hinsinger, P.; Plassard, C.; Jaillard, B. Rhizosphere: A new frontier for soil biogeochemistry. J. Geochem. Explor. 2006, 88, 210-213. [CrossRef]

59. Mishra, A.; Mishra, S.P.; Arshi, A.; Agarwal, A.; Dwivedi, S.K. Plant-Microbe Interactions for Bioremediation and Phytoremediation of Environmental Pollutants and Agro-ecosystem Development BT-Bioremediation of Industrial Waste for Environmental Safety: Volume II: Biological Agents and Methods for Industrial Waste M; Bharagava, R.N., Saxena, G., Eds.; Springer: Singapore, 2019; pp. 415-436, ISBN 978-981-13-3426-9.

60. Podda, F.; Zuddas, P.; Minacci, A.; Pepi, M.; Baldi, F. Heavy metal coprecipitation with hydrozincite $\left[\mathrm{Zn}_{5}\left(\mathrm{CO}_{3}\right)_{2}(\mathrm{OH})_{6}\right]$ from mine waters caused by photosynthetic microorganisms. Appl. Environ. Microbiol. 2000, 66, 5092-5098. [CrossRef] [PubMed]

61. Wanty, R.B.; Podda, F.; De Giudici, G.; Cidu, R.; Lattanzi, P. Zinc isotope and transition-element dynamics accompanying hydrozincite biomineralization in the Rio Naracauli, Sardinia, Italy. Chem. Geol. 2013, 337-338, 1-10. [CrossRef]

62. Medas, D.; De Giudici, G.; Podda, F.; Meneghini, C.; Lattanzi, P. Apparent energy of hydrated biomineral surface and apparent solubility constant: An investigation of hydrozincite. Geochim. Cosmochim. Acta 2014, 140, 349-364. [CrossRef]

63. Sanna, R.; Medas, D.; Podda, F.; Meneghini, C.; Casu, M.; Lattanzi, P.; Scorciapino, M.A.; Floris, C.; Cannas, C.; De Giudici, G. Binding of bis-(2-ethylhexyl) phthalate at the surface of hydrozincite nanocrystals: An example of organic molecules absorption onto nanocrystalline minerals. J. Colloid Interface Sci. 2015, 457. [CrossRef] [PubMed] 
64. Ehrlich, H.L.; Newman, D.K.; Kappler, A.; Newman, D.K.; Kappler, A. Ehrlich's Geomicrobiology, Sixth Edition; Ehrlich, H., Newman, D., Kappler, A., Eds.; CRC Press: Boca Raton, FL, USA, 2015; ISBN 978-1-4665-9240-7.

65. Bertin, C.; Yang, X.; Weston, L.A. The role of root exudates and allelochemicals in the rhizosphere. Plant Soil 2003, 256, 67-83. [CrossRef]

66. Leisso, R.; Rudell, D.; Mazzola, M. Targeted Metabolic Profiling Indicates Apple Rootstock Genotype-Specific Differences in Primary and Secondary Metabolite Production and Validate Quantitative Contribution From Vegetative Growth. Front. Plant Sci. 2018, 9, 1336. [CrossRef]

67. Deng, X.; Xia, Y.; Hu, W.; Zhang, H.; Shen, Z. Cadmium-induced oxidative damage and protective effects of N-acetyl-1-cysteine against cadmium toxicity in Solanum nigrum L. J. Hazard. Mater. 2010, 180, 722-729. [CrossRef]

68. Álvarez, C.; Ángeles Bermúdez, M.; Romero, L.C.; Gotor, C.; García, I. Cysteine homeostasis plays an essential role in plant immunity. New Phytol. 2012, 193, 165-177. [CrossRef] [PubMed]

69. Roblin, G.; Octave, S.; Faucher, M.; Fleurat-Lessard, P.; Berjeaud, J.-M. Cysteine: A multifaceted amino acid involved in signaling, plant resistance and antifungal development. Plant Physiol. Biochem. 2018, 129, 77-89. [CrossRef] [PubMed]

70. Fujimaki, M.; Kato, S.; Kurata, T. Pyrolysis of Sulfur-containing Amino Acids. Agric. Biol. Chem. 1969, 33, 1144-1151. [CrossRef]

71. Weiss, I.M.; Muth, C.; Drumm, R.; Kirchner, H.O.K. Thermal decomposition of the amino acids glycine, cysteine, aspartic acid, asparagine, glutamic acid, glutamine, arginine and histidine. BMC Biophys. 2018, 11, 2. [CrossRef]

72. Kato, S.; Kurata, T.; Ishiguro, S.; Fujimaki, M. Additional volatile compounds produced by pyrolysis of sulfurcontaining amino acids. Agric. Biol. Chem. 1973, 37, 1759-1761. [CrossRef]

73. Hales, M.C.; Frost, R.L. Thermal analysis of smithsonite and hydrozincite. J. Therm. Anal. Calorim. 2008, 91, 855-860. [CrossRef]

74. Kanari, N.; Mishra, D.; Gaballah, I.; Dupré, B. Thermal decomposition of zinc carbonate hydroxide. Thermochim. Acta 2004, 410, 93-100. [CrossRef]

75. Alkaç, D.; Atalay, Ü. Kinetics of thermal decomposition of Hekimhan-Deveci siderite ore samples. Int. J. Miner. Process. 2008, 87, 120-128. [CrossRef]

76. Gotor, F.J.; Macías, M.; Ortega, A.; Criado, J.M. Comparative study of the kinetics of the thermal decomposition of synthetic and natural siderite samples. Phys. Chem. Miner. 2000, 27, 495-503. [CrossRef]

77. Hurst, V.J.; Kunkle, A.C. Dehydroxylation, Rehydroxylation, and Stability of Kaolinite. Clays Clay Miner. 1985, 33, 1-14. [CrossRef]

78. Ding, S.; Zhang, L.; Ren, X.; Xu, B.; Zhang, H.; Ma, F. The Characteristics of Mechanical Grinding on Kaolinite Structure and Thermal Behavior. Energy Procedia 2012, 16, 1237-1240. [CrossRef]

79. Franceschi, V.R.; Horner, H.T. Calcium oxalate crystals in plants. Bot. Rev. 1980, 46, 361-427. [CrossRef]

80. De la Fuente, V.; Rufo, L.; Sánchez-Gavilán, I.; Ramírez, E.; Rodríguez, N.; Amils, R. Plant Tissues and Embryos Biominerals in Sarcocornia pruinosa, a Halophyte from the Río Tinto Salt Marshes. Minerals 2018, 8, 505. [CrossRef]

81. Quintana, J.R.; Cala, V.; Moreno, A.M.; Parra, J.G. Effect of heating on mineral components of the soil organic horizon from a Spanish juniper (Juniperus thurifera L.) woodland. J. Arid Environ. 2007, 71, 45-56. [CrossRef]

82. Iglesias, T.; Cala, V.; Gonzalez, J. Mineralogical and chemical modifications in soils affected by a forest fire in the Mediterranean area. Sci. Total Environ. 1997, 204, 89-96. [CrossRef]

83. Garvie, L.A.J. Mineralogy of paloverde (Parkinsonia microphylla) tree ash from the Sonoran Desert: A combined field and laboratory study. Am. Mineral. 2016, 101, 1584-1595. [CrossRef]

84. Nanda, S.; Mohanty, P.; Pant, K.K.; Naik, S.; Kozinski, J.A.; Dalai, A.K. Characterization of North American Lignocellulosic Biomass and Biochars in Terms of their Candidacy for Alternate Renewable Fuels. Bioenergy Res. 2013, 6, 663-677. [CrossRef]

85. Zornoza, R.; Moreno-Barriga, F.; Acosta, J.A.; Muñoz, M.A.; Faz, A. Stability, nutrient availability and hydrophobicity of biochars derived from manure, crop residues, and municipal solid waste for their use as soil amendments. Chemosphere 2016, 144, 122-130. [CrossRef]

86. Roy, D.M.; Mumpton, F.A. Stability of minerals in the system $\mathrm{ZnO}-\mathrm{SiO}_{2}-\mathrm{H}_{2} \mathrm{O}$. Econ. Geol. 1956, 51, $432-443$. [CrossRef] 
87. Takesue, M.; Hayashi, H.; Smith, R.L. Thermal and chemical methods for producing zinc silicate (willemite): A review. Prog. Cryst. Growth Charact. Mater. 2009, 55, 98-124. [CrossRef]

88. Kan, T.; Strezov, V.; Evans, T.J. Lignocellulosic biomass pyrolysis: A review of product properties and effects of pyrolysis parameters. Renew. Sustain. Energy Rev. 2016, 57, 1126-1140. [CrossRef]

89. Jahirul, M.; Rasul, M.; Chowdhury, A.; Ashwath, N.; Jahirul, M.I.; Rasul, M.G.; Chowdhury, A.A.; Ashwath, N. Biofuels Production through Biomass Pyrolysis-A Technological Review. Energies 2012, 5, 4952-5001. [CrossRef]

90. Xu, X.; Cao, X.; Zhao, L. Comparison of rice husk- and dairy manure-derived biochars for simultaneously removing heavy metals from aqueous solutions: Role of mineral components in biochars. Chemosphere 2013, 92, 955-961. [CrossRef] [PubMed]

91. Fang, Y.; Singh, B.; Singh, B.P. Effect of temperature on biochar priming effects and its stability in soils. Soil Biol. Biochem. 2015, 80, 136-145. [CrossRef]

92. Lehmann, J.; Rillig, M.C.; Thies, J.; Masiello, C.A.; Hockaday, W.C.; Crowley, D. Biochar effects on soil biota-A review. Soil Biol. Biochem. 2011, 43, 1812-1836. [CrossRef]

93. Lehmann, J.; Gaunt, J.; Rondon, M. Bio-char Sequestration in Terrestrial Ecosystems-A Review. Mitig. Adapt. Strateg. Glob. Chang. 2006, 11, 403-427. [CrossRef]

94. Smith, P. Soil carbon sequestration and biochar as negative emission technologies. Glob. Chang. Biol. 2016, 22, 1315-1324. [CrossRef]

95. Zhao, B.; O'Connor, D.; Zhang, J.; Peng, T.; Shen, Z.; Tsang, D.C.W.; Hou, D. Effect of pyrolysis temperature, heating rate, and residence time on rapeseed stem derived biochar. J. Clean. Prod. 2018, 174, 977-987. [CrossRef]

96. Vassilev, S.V.; Baxter, D.; Andersen, L.K.; Vassileva, C.G. An overview of the composition and application of biomass ash. Part 1. Phase-mineral and chemical composition and classification. Fuel 2013, 105, 40-76. [CrossRef]

97. Xu, X.; Zhao, Y.; Sima, J.; Zhao, L.; Mašek, O.; Cao, X. Indispensable role of biochar-inherent mineral constituents in its environmental applications: A review. Bioresour. Technol. 2017, 241, 887-899. [CrossRef]

98. Xu, X.; Cao, X.; Zhao, L. Comparison of rice husk- and dairy manure-derived biochars for simultaneously removing heavy metals from aqueous solutions: Role of mineral components in biochars. Chemosphere 2013, 92, 955-961. [CrossRef] [PubMed]

99. Vassilev, S.V.; Baxter, D.; Andersen, L.K.; Vassileva, C.G. An overview of the composition and application of biomass ash.: Part 2. Potential utilisation, technological and ecological advantages and challenges. Fuel 2013, 105, 19-39. [CrossRef]

100. Thy, P.; Jenkins, B.M.; Grundvig, S.; Shiraki, R.; Lesher, C.E. High temperature elemental losses and mineralogical changes in common biomass ashes. Fuel 2006, 85, 783-795. [CrossRef] 